\title{
MACROECONOMIC FACTORS AND OIL FUTURES PRICES: A DATA-RICH MODEL
}

\author{
Paolo Zagaglia*
}

This version: February 10, 2009

\begin{abstract}
I study the dynamics of oil futures prices in the NYMEX using a large panel dataset that includes global macroeconomic indicators, financial market indices, quantities and prices of energy products. I extract common factors from these series and estimate a Factor-Augmented Vector Autoregression for the maturity structure of oil futures prices. I find that latent factors generate information that, once combined with that of the yields, improves the forecasting performance for oil prices. Furthermore, I show that a factor correlated to purely financial developments contributes to the model performance, in addition to factors related to energy quantities and prices.
\end{abstract}

KEYWORDS: Crude oil, futures markets, factor models.

JeL Classification: C53, D51, E52.

\footnotetext{
*Department of Economics, Stockholm University, pzaga@ne.su.se. This work started when I was a visiting scholar in the Research Unit of the Bank of Finland, and was completed during a consultancy assignment for the Research Department of Sveriges Riksbank. I acknowledge the warm hospitality of both institutions. I am deeply grateful to Vincent Brousseau and Tarja Yrjölä for help in constructing the dataset. Efrem Castelnuovo, Juha Kilponen, Massimiliano Marzo and Alistair Milne contributed with relevant suggestions and constructive criticism. The usual disclaimer applies.
} 


\section{Introduction}

During the past year, oil prices have made the headlines of the financial press almost every day. Since the beginning 2008, the spot price of crude oil traded in the New York Mercantile Exchange (NYMEX) has almost doubled at peak. This has raised serious concerns among market participants and policymakers worldwide. Comments released to the press have often denoted a deep disagreement on the causes of the price spikes and, in general, on the mechanics of oil market.

Bernanke (2008) has represented the central bankers' view in a timely manner, stating that

"...the price of oil has risen significantly in terms of all major currencies, suggesting that factors other than the dollar, notably shifts in the underlying global demand for and supply of oil, have been the principal drivers of the increase in prices. (...) Another concern that has been raised is that financial speculation has added markedly to upward pressures on oil prices. (...) However, if financial speculation were pushing oil prices above the levels consistent with the fundamentals of supply and demand, we would expect inventories of crude oil and petroleum products to increase as supply rose and demand fell. But in fact, available data on oil inventories show notable declines over the past year."

Trichet (2008) clarifies the role that factors unrelated to energy demand and supply can play in oil markets: ${ }^{1}$

"I am not sure that speculation is the major culprit for what we are observing. The major issues are associated with supply and demand... It is not the futures market itself that is the problem. The problem is that this is acrossthe-board reallocation of portfolios that gives more weight to commodities in general."

Since oil commodities are traded through futures and derivatives contracts, market views shape the pricing of oil commodities. In this sense, the financial press has pushed the hypothesis that purely financial factors, or 'speculation', have been behind the recent spikes (see Chung, 2008 and Mackintosh, 2008).

The academic literature on the macroeconomics of oil prices presents the same dichotomy. For instance, Kilian (2008b) suggests that a proper measurement of the business cycle effects of energy prices requires disentangling the role of demand supply shocks in energy markets. Kilian (2008a) decomposes the real price of crude oil into supply shocks,

\footnotetext{
${ }^{1}$ Also quoted in Barber (2008).
} 
shocks to the global demand for industrial commodities, and demand shocks that are idiosyncratic to the oil market. The role of energy quantity factors is stressed also in Alquist and Kilian (2008), who show that spread between oil futures prices of different maturities are related to uncertainty about supply shortfalls.

The literature on the financial determinants of oil prices has produced a number of results on the role of uncertainty for oil pricing. Askari and Krichene (2008) model the jump intensity of daily crude oil prices between 2002 and 2006. They find that measures of market expectations extracted from call and put option prices have incorporated no change in underlying fundamentals in the short term. Chong and Miffre (2006) document the presence of a significant pattern of risk premia earned by investors on a number of commodities futures since 1979, including crude oil. Gorton, Hayashi and Rouwenhorst (2007) show that, although commercial positions on oil futures are correlate with inventory signals, they do not determine risk premia. Finally, Marzo, Spargoli and Zagaglia (2009) examine the predictive content for futures prices of a specific type of oil derivative contract, namely oil spreads. Their results indicate that oil spread prices have stable predictive power for futures prices, thus supporting the hypothesis that speculative motives matter.

A number of key questions related to price formation in oil markets is not dealt with in the literature. The issue of causality between spot and futures prices across the maturity structure is largely unsettled. Suppose that oil futures contain information about spot prices. Omitting futures prices would bias the results in favour of a strong role for demandsupply factors to drive the spot price. It is not clear what the channels are for oil prices to have macroeconomic impact. Moreover, the role of macroeconomic factors for the dynamics of oil prices has been studied in isolation from the conditions prevailing in financial markets. This is at odds with what is suggested by Trichet (2008) with reference to recent episodes.

In this paper, I exploit the information from a large panel of energy prices and quantities, macroeconomic and financial data to study the dynamics of the term structure of futures prices for crude oil. I assume that the available time series are noisy measures of broad concepts, such as demand and supply. Hence, I treat these variables as unobservable. Like Bernanke, Boivin and Eliasz (2005), I extract common factors. I model the joint dynamics of the factors and the oil prices in a 'Factor-Augmented' vector autoregression (FAVAR).

This modelling strategy has already been applied by Mönch (2005) to construct a noaffine model for the yield curve of government bonds. There are multiple advantages from following this approach. The first one is that this can capture the underlying dynamics in oil prices generated by latent factors of different nature. The FAVAR allows to model the relevant maturity spectrum of oil futures prices in a flexible way.

The panel dataset from which I extract common components include over 200 data series with detailed information on energy demand and supply, energy prices, macroeco- 
nomic and financial variables. I show that a latent factor correlated with the open interest on oil futures prices contributes significantly to the joint model of the yields. This appears to corroborate the conjecture of Trichet (2008) on the financial determinants of oil prices. The other factors are strongly correlated with data on energy quantity and prices, as typically suggested by the macroeconomics literature. I find that augmenting the information from the term structure of oil futures prices with latent factors improves the forecasting performance of the model.

This paper is organized as follows. In section 2, I outline the structure of the FAVAR model. Section 3 presents the dataset. Section 4 describes the results. Final remarks are presented in section 5 .

\section{The Factor Augmented VAR Model}

The model presented here is based on the assumption that the futures price for one maturity is driven both by the prices of the other maturities, and by macroeconomic shocks. The macroeconomic determinants are proxied by unobservable factors that summarize the common information in a large number of time series. The joint dynamics of the observable an unobservable variables in modelled in the FAVAR model of Bernanke, Boivin and Eliasz (2005).

The general form of the FAVAR can be written as

$$
\left[\begin{array}{l}
F_{t} \\
Y_{t}
\end{array}\right]=\mu+\Phi(L)\left[\begin{array}{l}
F_{t-1} \\
Y_{t-1}
\end{array}\right]+\Sigma \nu_{t}
$$

where $\Phi(L)$ is a $(k+m) \times(k+m)$ matrix of lag polynomials, $\nu_{t}$ is a $(k+m) \times 1$ vector of standardized normal shocks. $Y_{t}=\left[y_{t}^{\prime}, y_{t-1}^{\prime} \ldots\right]$ is a vector $m \times 1$ of observed variables. The unobservable factors are collected in the $k \times 1$ vector $F_{t}=\left[f_{t}^{\prime}, f_{t-1}^{\prime} \ldots\right]$. Equation 1 states that the dynamics of the factors is affected by its own lags, by the vector of observables, and by the shocks.

Equation 1 cannot be estimated without knowledge of $F_{t}$. For that purpose, a large number $p$ of series can be used to extract common factors. The 'information series' are collected in the vector $X_{t}$ with dimension $p \times 1$. The dynamic factor model of Stock and Watson (2002) can then be used to obtain $F_{t}$

$$
X_{t}=\Lambda^{f}(L) f_{t}+\Lambda^{y}(L) y_{t}+\epsilon_{t} .
$$

If $p>k$, and $k$ is small, the dynamic model 2 can be rewritten as a static factor model with fixed loadings

$$
X_{t}=\Lambda^{f} F_{t}+\Lambda^{y} Y_{t}+\epsilon_{t} .
$$


Bernanke, Boivin and Eliasz (2005) propose two methods for estimating the model 1-3. The first one is the 'diffusion index' approach of Stock and Watson (2002), which consists itself of two steps. In the first step, equation 3 is used to estimate the unobservable factors $F_{t}$ through principal components analysis. The estimated $\hat{F}_{t}$ is then fit to the FAVAR model 1. The second method for the estimation of the model follows a single-step Bayesian likelihood approach. Bernanke, Boivin and Eliasz (2005) discuss a Gibbs sampler that approximates the marginal posterior densities of both the factors and the parameters. Since it is not clear a priori which estimation method delivers the results that are most desirable, Bernanke, Boivin and Eliasz (2005) estimate the model using both approaches, and find that they yield similar outcomes. In this paper, I apply the two-step procedure.

The asymptotic principal component method of Stock and Watson (2002) estimates the factors by recovering the space of $X_{t}$ spanned by both $F_{t}$ and $Y_{t}$. Denote by $V$ the eigenvectors corresponding to the $k$ largest eigenvalues of the variance-covariance matrix $X X^{\prime} / k$. The estimates of the factors are obtained from

$$
\hat{F}=\sqrt{T} V
$$

and the loadings are

$$
\hat{\Lambda}=\sqrt{T} X^{\prime} V
$$

\section{The dataset}

I use monthly data from January 1992 until March 2008 for a total of 193 observations for each series. The vector $Y_{t}$ consists of returns on the spot price for WTI crude oil traded in the New York Mercantile Exchange (NYMEX), and on futures prices with maturities of 1 , 6 and 12 months. ${ }^{2}$ The panel dataset used for the extraction of the factors comprises 239 series that are meant to capture the macroeconomic, financial and geographic forces that move oil prices. The complete list of the series, the sources and the choice of filtering are reported in Appendix A.

Oil prices in the NYMEX respond to global supply and demand factors. Hence, the dataset includes series that are publicly available on petroleum stocks and consumption in the major OECD countries. Since this information is not available for the major emerging economies (Russia, India and China), the industrial production index is used as a proxy for consumption pressures. Instead, crude oil production data account for the entire range of oil producers worldwide. Almost half the series on energy quantities described in Appendix A refer to the U.S. In particular, there is detailed information on the use of all the available energy sources across sectors of the economy, including the energy products derived from

\footnotetext{
${ }^{2}$ Returns are computed as the first difference of the log.
} 
petroleum and natural gas. There are indicators on rigging and drilling activities in the U.S., as well as on alternative sources of energy such as ethanol. I use around 50 price indices that are related with U.S. imports and refining. I control for the role of shipment prices to the Mediterranean sea and from the Gulf to Northern Europe.

The macroeconomic part of the dataset consists of on measures of monetary aggregates, prices indices, indicators of confidence and bilateral exchange rates for the U.S. economy. Since the stability of the Dollar exchange rate is often pointed to as a key factor for oil prices, I use the global hazard indicator of Brousseau and Scacciavillani (1999). This is a measure of risk in foreign exchange markets calculated from implied volatilities of currency options. Following the lead from the previous quotation of Bernanke (2008), the dataset includes information on the open interest and the volumes of traded futures contracts, as well as prices of crude oil spreads. In particular, crude oil spreads are over-the-counter derivatives. As Marzo, Spargoli and Zagaglia (2009) show, these contracts have predictive content for oil futures prices, and can provide information on the speculative motive for trading oil. Finally, the dataset comprises the prices of stocks of major oil companies, and a number of bond and stock indices.

\section{Results}

\subsection{Model specification}

In the first part of the estimation, I extract common factors from the panel dataset using static principal components along the lines of Stock and Watson (2002). The first 8 factors account for $80 \%$ of the variance in the dataset. Table 1 reports the fraction of variance explained by the first four factors. These factors account for a sizeable proportion of the total variation, namely around $50 \%$. They exhibit a low degree of persistence. The estimated autocorrelation coefficients are however quite different across factors.

I include the first four factors in the FAVAR model for two reasons. Testing for the optimal number of factors using the statistical framework of Bai and Ng (2008) points in favour of the use of these factors. On more general grounds, the VAR model presents a tradeoff between parsimony and fit. Various experiments suggest that the results are qualitatively unaltered by the inclusion of additional factors. ${ }^{3}$ A similar issue arises for the choice of the lag length. Information criteria suggest that 2 lags provide a reasonable specification of the model.

\subsection{Factor estimates}

The factors extracted from the panel have no structural interpretation unless identifying assumptions are imposed. In order to provide some understanding on the information they

\footnotetext{
${ }^{3}$ These results are available from the author upon request.
} 
convey, I regress the factors on the variables of the panel. Table 2 reports the variance explained by the five series that are most correlated with the factors. The first factor is strongly correlated with a price index of crude oil imports. This can be interpreted as a cost indicator of the price pressure on oil futures. The second and third factors are related to stock volumes of oil-related products. This has to do with the intermediate demand for crude oil. Finally, the fourth factors is correlated with a purely financial variables that is disconnected from real developments in oil markets. This provides support to the claim that financial factors contribute to the determination of oil prices.

Figure 1 plots the estimated factors together with the most correlated series of the panel dataset. The factor loadings are plotted in figure 2. I break down the contribution to the loadings of each factor by three groups of series, divided into energy prices, energy quantities and macro and financial data. The contributions to the factors differ largely across series. Energy prices provide the largest contribution to the first factor. Energy quantities instead account for the largest weights in the second and third factors. Finally, macro and financial series determine the largest fraction of the fourth factor. These considerations support the economic interpretation of the factors discussed earlier.

\subsection{Preliminary evidence on the role of factors}

In order to understand the relation between the factors and the the return on oil futures prices at different maturities, I report the correlation between the yields and the lagged factors in Table 3. The correlations differ in terms of size and sign across factors. The first factor has a large and positive contemporaneous correlation with all the returns. This is consistent with the interpretation of measure of cost pressure on futures prices. The other three facts are less correlated with the yields. The sign of the contemporaneous correlation on the second and third factors is negative, in agreement with the idea that available stocks provide a buffer to prices. The third factor is however weakly correlated, with the magnitude of correlation increasing at longer lags. Overall, this preliminary evidence suggests that not all the factors have predictive power for the yields at various lags.

To explore further this issue, I estimate unrestricted regressions of the yields on the factors, which takes the form

$$
Y_{t}=\mu+\Lambda F_{t}+\epsilon_{t}
$$

Table 4 reports the parameters estimates and the fraction of explained variation. Two observations arise. The first one concerns the fact that only the first and the fourth factors have statistically significant coefficients for regressions of all the yields. The estimated coefficients are the signs one would expect from the correlation analysis. The second consideration is that the regressions explain large fractions of the variation in the yields of 
up to 6 months of maturity. Moreover, the longer the maturity, the more limited the scope of the factors for explaining the dynamics of the yields. For 1-year oil futures, the joint predictive power of the factors becomes low, as the $R^{2}$ declines to approximately $12 \%$.

\subsection{Parameter estimates}

Before estimating the factor-augmented VAR, I evaluate the persistence of all the variables. In order to investigate the null of a unit root, I run the tests proposed by Dickey and Fuller (1979) and Phillips and Perron (1988). Instead of relying on the standard formulation of these tests, I apply the state-of-the-art modifications proposed by Perron and $\mathrm{Ng}$ (1996, 2001). ${ }^{4}$ Table 5 reports the test statistics. The results indicate that the null of a unit root is rejected for all the variables. Hence, all the series to be included in the FAVAR can be modelled as stationary variables.

The estimates of the FAVAR model are detailed in Table 6. The upper part of the diagonal of the coefficient matrix $\Gamma_{1}$ suggests that only the first fact displays a certain degree of persistence. Additional evidence on the relation between the factors and the returns can be obtained through pairwise Granger-causality tests in the VAR. These are $F$ tests for zero restrictions on the lagged coefficients of a variable onto another. Table 7 reports the test statistics and the $p$-values for the null of Granger causality of the factors for the yields, and vice versa. The first panel shows that not all the factors have predictive power for the yields. In this sense, the most important factor is the first one. The second factor, instead, does not Granger cause any of the yields. Since these are bivariate tests, they provide no information on the indirect relation between variables. For instance, the second factor might Granger cause another factor, which can in turn have predictive power on the yields. Interestingly, the second panel shows that the yields Granger cause of the factors. This highlights one of the advantages of the modelling strategy pursued in this paper, namely capturing the interaction between the observable and non-observable variables.

Figure 3 plots the fitted series in-sample. The fitted series do not succeed in capturing the large variation that characterizes the historical data. However, they fit the peaks relatively well. In the case of the returns on 1-year futures, the model replicates the large swing of the sample that takes place in 1996-1998.

\subsection{Out-of-sample forecasts}

In this section, I compare the performance for out-of-sample forecasts from the FAVAR with that of alternative models. In particular, the competitor models are

\footnotetext{
${ }^{4}$ These are based on the use of Generalized Least Squares detrended data for the estimation of the spectral density matrix at zero frequency, and on the computation of a class of improved selection criteria for the choice of the order of the underlying autoregression. Perron and $\mathrm{Ng}$ (1996) shows that both aspects improve the small-sample properties of the tests.
} 
- a VAR on yields only

$$
\hat{Y}_{t+h \mid t}=\hat{\mu}+\hat{\Lambda} Y_{t}
$$

- a factor-only VAR

$$
\hat{Y}_{t+h \mid t}=\hat{\mu}+\hat{\Lambda} F_{t}
$$

- a random walk

$$
\hat{Y}_{t+h \mid t}=Y_{t}
$$

The forecasting exercise is run as follows. I initialize the parameter estimates on data until December 2002. The forecasts are then computed for various horizons, and the model estimates are updated recursively by estimating with one additional data-point at the time.

Table 8 reports the root mean squared errors (RMSE). Table 9 lists the squared errors relative to those of a random walk. The FAVAR generates the best forecasts for 1- and 3 -month and 1-year yields at short horizons. The VAR with yields only is instead the best predictor for yields 6 months ahead. For forecast horizons longer than 3 months, the FAVAR generates the same squared errors of either the VAR with yields only or the factoronly model. However, the squared errors generated by the models are rather close. This means that no major reduction in RMSE are obtained from choosing the best performing model. To summarize, the joint information from factors and yields improves to a limited extent the predictive power for the yields at short horizons.

\section{Conclusion}

This paper models the dynamics of the term structure of oil futures prices by using information from a panel dataset including over 230 series with global macroeconomic indicators, financial market indices, quantities and prices of energy products. I estimate a FactorAugmented Vector Autoregression with latent factors extracted from the panel. I show that latent factors generate information which, once combined with that of the yields, improves the forecasting performance for oil prices. Furthermore, I find that a factor correlated to purely financial developments contributes to the model performance, in addition to factors related to energy quantities and prices.

The results presented here can be extended in a number of directions. I am planning to use Bayesian model averaging to study the performance of the best-performing subset of factors for forecasting the term structure of oil prices. Moreover, the factors could be 
used to identity the impact of oil demand and supply shocks. In this sense, it would be important to understand what role purely financial market variables can play for the persistence and magnitude of the estimated shocks.

\section{References}

Alquist, Ron, and Lutz Kilian (2008), "What Do We Learn from the Price of Crude Oil Futures?," unpublished manuscript, University of Michigan.

Askari, Hossein, and Noureddine Krichene (2008), "Oil Price Dynamics (2002Ú2006)," Energy Economics, 30(5), 2134-2153.

Authers, John (2008), "The Short View: Oil and US banks," Financial Times, July 23.

Bai, Jushan, and Serena Ng (2008), "Determining the Number of Factors in Approximate Factor Models," Econometrica, 70(1), 191-221.

Barber, Tony (2008), "Trichet rejects oil price link to trading," Financial Times, June 25.

Bernanke, Ben S., Jean Boivin, and Pitr Eliasz (2008), "Measuring the Effects of Monetary Policy: A Factor-Augmented Vector Autoregressive (FAVAR) Approach," Quarterly Journal of Economics, 120(1), 387-422.

Bernanke, Ben S. (2008), "Semiannual Monetary Policy Report to the Congress Before the Committee on Banking, Housing, and Urban Affairs," U.S. Senate, Washington, July 15 .

Brousseau, Vincent, and Fabio Scacciavillani (1999), "A global hazard index for the world foreign exchange markets," ECB Working Paper, No. 1.

Chong, James, and Joelle Miffre (2006), "Conditional Risk Premia and Correlations in Commodity Futures Markets," unpublished manuscript, EDHEC Business School.

Chung, Joanna (2008), "Fund accused of manipulating oil price," Financial Times, July 24.

Dickey, D. A., and W. A. Fuller (1979), "Distribution of the Estimators for Autoregressive Time Series with a Unit Root", Journal of the American Statistical Association, 74.

Elliott, G., T. J. Rothenberg, and J. H. Stock (1996), "Efficient Tests for an Autoregressive Unit Root," Econometrica, 64.

Gorton, Gary B., Fumio Hayashi, and K. Geert Rouwenhorst (2007), "The Fundamentals of Commodity Futures Returns", NBER Working Paper, 13249.

Kilian, Lutz (2008a), "Not All Oil Price Shocks Are Alike: Disentangling Demand and Supply Shocks in the Crude Oil Market," unpublished manuscript, University of Michigan.

Kilian, Lutz (2008b), "The Economic Effects of Energy Price Shocks," unpublished manuscript, University of Michigan. 
Mackintosh, James (2008), "Hedge funds have worst month since 2000," Financial Times, July 26.

Marzo, Massimiliano, Fabrizio Spargoli, and Paolo Zagaglia (2008), "The Information Content of Oil Spreads: How Far Do They Do?," unpublished manuscript, Sveriges Riksbank, January.

Mönch, Emanuel, (2005), "Forecasting the Yield Curve in a Data-Rich Environment: A No-Arbitrage Factor-Augmented VAR Approach", ECB Working Paper, 544.

Phillips, P. C. B., and P. Perron (1988), ""Testing for a Unit Root in Time Series Regression", Biometrika, 75,

Perron, Pierre, and Serena Ng (1996), "Useful Modifications to Unit Root Tests with Dependent Errors and Their Local Asymptotic Properties," Review of Economic Studies, 63.

Perron, Pierre, and Serena Ng (2001), "Lag Length Selection and the Construction of Unit Root Tests with Good Size and Power," Econometrica, 69.

Sargan, J. D., and A. Bhargava (1993), "Testing for Residuals from Least Squares Regression Being Generated by Gaussian Random Walk," Econometrica, 51.

Stock, James H., and Mark W. Watson (2002), "Macroeconomic Forecasting Using Diffusion Indexes," Journal of Business and Economic Statistics, 20, 147-162.

Trichet, Jean-Claude (2008), "Hearing at the Economic and Monetary Affairs Committee of the European Parliament," Brussels, 25 June.

Permanent Subcommittee on Investigations (2008), "The Role of Market Speculation in Rising Oil and Gas Prices: A Need to Put the Cop Back on the Beat," Staff Report, United States Senate, Committee on Homeland Security and Governmental Affairs, June 272006. 


\section{A Panel dataset}

\begin{tabular}{|c|c|c|c|}
\hline Series & Unit & Treatment & Source \\
\hline \multicolumn{4}{|l|}{ PRICE DATA } \\
\hline F.O.B. Cost of Crude Oil Imports From Angola & Nominal Dollars per Barrel & Diff, log & EIA \\
\hline F.O.B. Cost of Crude Oil Imports From Colombia & Nominal Dollars per Barrel & Diff, log & EIA \\
\hline F.O.B. Cost of Crude Oil Imports From Mexico & Nominal Dollars per Barrel & Diff, log & EIA \\
\hline F.O.B. Cost of Crude Oil Imports From Nigeria & Nominal Dollars per Barrel & Diff, log & EIA \\
\hline F.O.B. Cost of Crude Oil Imports From Saudi Arabia & Nominal Dollars per Barrel & Diff, log & EIA \\
\hline F.O.B. Cost of Crude Oil Imports From United Kingdom & Nominal Dollars per Barrel & Diff, log & EIA \\
\hline F.O.B. Cost of Crude Oil Imports From Venezuela & Nominal Dollars per Barrel & Diff, log & EIA \\
\hline F.O.B. Cost of Crude Oil Imports From Persian Gulf & Nominal Dollars per Barrel & Diff, log & EIA \\
\hline Average F.O.B. Cost of Crude Oil Imports From All OPEC & Nominal Dollars per Barrel & Diff, log & EIA \\
\hline Average F.O.B. Cost of Crude Oil Imports From All Non-OPEC & Nominal Dollars per Barrel & Diff, log & EIA \\
\hline Landed Cost of Crude Oil Imports From Angola & Nominal Dollars per Barrel & Diff, log & EIA \\
\hline Landed Cost of Crude Oil Imports From Canada & Nominal Dollars per Barrel & Diff, log & EIA \\
\hline Landed Cost of Crude Oil Imports From Colombia & Nominal Dollars per Barrel & Diff, log & EIA \\
\hline Landed Cost of Crude Oil Imports From Mexico & Nominal Dollars per Barrel & Diff, log & EIA \\
\hline Landed Cost of Crude Oil Imports From Nigeria & Nominal Dollars per Barrel & Diff, log & EIA \\
\hline Landed Cost of Crude Oil Imports From Saudi Arabia & Nominal Dollars per Barrel & Diff, log & EIA \\
\hline Landed Cost of Crude Oil Imports From Venezuela & Nominal Dollars per Barrel & Diff, log & EIA \\
\hline Landed Cost of Crude Oil Imports From Persian Gulf & Nominal Dollars per Barrel & Diff, log & EIA \\
\hline Landed Cost of Crude Oil Imports From All OPEC & Nominal Dollars per Barrel & Diff, log & EIA \\
\hline Landed Cost of Crude Oil Imports From All Non-OPEC & Nominal Dollars per Barrel & Diff, log & EIA \\
\hline Unleaded Regular Gasoline, U.S. City Average Retail Price & Nominal Cents per Gallon & Diff, log & EIA \\
\hline Unleaded Premium Gasoline, U.S. City Average Retail Price & Nominal Cents per Gallon & Diff, log & EIA \\
\hline All Types of Gasoline, U.S. City Average Retail Price & Nominal Cents per Gallon & Diff, log & EIA \\
\hline Refiner Price of Finished Motor Gasoline to End Users & Nominal Cents per Gallon & Diff, log & EIA \\
\hline Refiner Price of Finished Aviation Gasoline to End Users & Nominal Cents per Gallon & Diff, log & EIA \\
\hline Refiner Price of Kerosene-Type Jet Fuel to End Users & Nominal Cents per Gallon & Diff, log & EIA \\
\hline Refiner Price of Kerosene to End Users & Nominal Cents per Gallon & Diff, log & EIA \\
\hline Refiner Price of No. 2 Fuel Oil to End Users & Nominal Cents per Gallon & Diff, log & EIA \\
\hline Refiner Price of No. 2 Diesel Fuel to End Users & Nominal Cents per Gallon & Diff, log & EIA \\
\hline Refiner Price of Propane (Consumer Grade) to End Users & Nominal Cents per Gallon & Diff, log & EIA \\
\hline Refiner Price of Finished Motor Gasoline for Resale & Nominal Cents per Gallon & Diff, log & EIA \\
\hline Refiner Price of Finished Aviation Gasoline for Resale & Nominal Cents per Gallon & Diff, log & EIA \\
\hline Refiner Price of Kerosene-Type Jet Fuel for Resale & Nominal Cents per Gallon & Diff, log & EIA \\
\hline Refiner Price of Kerosene for Resale & Nominal Cents per Gallon & Diff, log & EIA \\
\hline Refiner Price of No. 2 Fuel Oil for Resale & Nominal Cents per Gallon & Diff, log & EIA \\
\hline Refiner Price of No. 2 Diesel Fuel for Resale & Nominal Cents per Gallon & Diff, log & EIA \\
\hline Refiner Price of Propane (Consumer Grade) for Resale & Nominal Cents per Gallon & Diff, log & EIA \\
\hline Refiner Price of Residual Fuel Oil, Percent, Resale & Nominal Cents per Gallon & Diff, log & EIA \\
\hline Refiner Price of Residual Fuel Oil, Percent, End Users & Nominal Cents per Gallon & Diff, log & EIA \\
\hline Refiner Price of Residual Fuel Oil, Resale & Nominal Cents per Gallon & Diff, log & EIA \\
\hline Refiner Price of Residual Fuel Oil, End Users & Nominal Cents per Gallon & Diff, log & EIA \\
\hline Refiner Price of Residual Fuel Oil, Average, Resale & Nominal Cents per Gallon & Diff, log & EIA \\
\hline Refiner Price of Residual Fuel Oil, Average, End Users & Nominal Cents per Gallon & Diff, log & EIA \\
\hline Shipment prices MED-UKC & doll./tonn & Diff, log & Platt's \\
\hline Shipment prices GULF -WEST & doll./tonn & Diff, log & Platt's \\
\hline \multicolumn{4}{|l|}{ STOCK AND FLOW DATA } \\
\hline Coal Consumed by the Commercial Sector & Trillion Btu & Diff, log & EIA \\
\hline Natural Gas Consumed by the Commercial Sector & Trillion Btu & Diff, perc. $\log$ & EIA \\
\hline Petroleum Consumed by the Commercial Sector & Trillion Btu & Diff, log & EIA \\
\hline Total Fossil Fuels Consumed by the Commercial Sector & Trillion Btu & Diff, perc. $\log$ & EIA \\
\hline Hydroelectric Power Consumed by the Commercial Sector & Trillion Btu & First diff. of level & EIA \\
\hline Geothermal Energy Consumed by the Commercial Sector & Trillion Btu & Diff, log & EIA \\
\hline Biomass Energy Consumed by the Commercial Sector & Trillion Btu & Diff, log & EIA \\
\hline Total Renewable Energy Consumed by the Commercial Sector & Trillion Btu & Diff, log & EIA \\
\hline Primary Energy Consumed by the Commercial Sector & Trillion Btu & Diff, perc. $\log$ & EIA \\
\hline Electricity Retail Sales to the Commercial Sector & Trillion Btu & Diff, perc. $\log$ & EIA \\
\hline Commercial Sector Electrical System Energy Losses & Trillion Btu & Diff, perc. $\log$ & EIA \\
\hline Total Energy Consumed by the Commercial Sector & Trillion Btu & Diff, perc. $\log$ & EIA \\
\hline Coal Consumed by the Electric Power Sector & Trillion Btu & Diff, perc. $\log$ & EIA \\
\hline Natural Gas Consumed by the Electric Power Sector & Trillion Btu & Diff, perc. $\log$ & EIA \\
\hline Petroleum Consumed by the Electric Power Sector & Trillion Btu & Diff, perc. $\log$ & EIA \\
\hline Total Fossil Fuels Consumed by the Electric Power Sector & Trillion Btu & Diff, perc. log & EIA \\
\hline Nuclear Electric Power Consumed by the Electric Power Sector & Trillion Btu & Diff, perc. log & EIA \\
\hline Hydroelectric Power Consumed by the Electric Power Sector & Trillion Btu & Diff, perc. log & EIA \\
\hline Geothermal Energy Consumed by the Electric Power Sector & Trillion Btu & Diff, log & EIA \\
\hline Solar/PV Energy Consumed by the Electric Power Sector & Trillion Btu & Diff, log & EIA \\
\hline Wind Energy Consumed by the Electric Power Sector & Trillion Btu & Diff, log & EIA \\
\hline Biomass Energy Consumed by the Electric Power Sector & Trillion Btu & Diff, log & EIA \\
\hline Total Renewable Energy Consumed by the Electric Power Sector & Trillion Btu & Diff, perc. $\log$ & EIA \\
\hline Electric Power Sector Electricity Net Imports & Trillion Btu & Diff, perc & EIA \\
\hline Primary Energy Consumed by the Electric Power Sector & Trillion Btu & Diff, perc. $\log$ & EIA \\
\hline Coal Consumed by the Residential Sector & Trillion Btu & Diff, log & EIA \\
\hline Natural Gas Consumed by the Residential Sector & Trillion Btu & Diff, perc. $\log$ & EIA \\
\hline Petroleum Consumed by the Residential Sector & Trillion Btu & Diff, perc. $\log$ & EIA \\
\hline Total Fossil Fuels Consumed by the Residential Sector & Trillion Btu & Diff, perc. $\log$ & EIA \\
\hline Geothermal Energy Consumed by the Residential Sector & Trillion Btu & Diff, log & EIA \\
\hline Solar/PV Energy Consumed by the Residential Sector & Trillion Btu & Diff, log & EIA \\
\hline
\end{tabular}




\begin{tabular}{|c|c|c|c|}
\hline Series & Unit & Treatment & Source \\
\hline Biomass Energy Consumed by the Residential Sector & Trillion Btu & Diff, log & EIA \\
\hline Total Renewable Energy Consumed by the Residential Sector & Trillion Btu & Diff, log & EIA \\
\hline Primary Energy Consumed by the Residential Sector & Trillion Btu & Diff, perc. $\log$ & EIA \\
\hline Electricity Retail Sales to the Residential Sector & Trillion Btu & Diff, perc. $\log$ & EIA \\
\hline Residential Sector Electrical System Energy Losses & Trillion Btu & Diff, perc. $\log$ & EIA \\
\hline Total Energy Consumed by the Residential Sector & Trillion Btu & Diff, perc. $\log$ & EIA \\
\hline Natural Gas Consumed by the Transportation Sector & Trillion Btu & Diff, log & EIA \\
\hline Petroleum Consumed by the Transportation Sector & Trillion Btu & Diff, perc. $\log$ & EIA \\
\hline Total Fossil Fuels Consumed by the Transportation Sector & Trillion Btu & Diff, perc. $\log$ & EIA \\
\hline Biomass Energy Consumed by the Transportation Sector & Trillion Btu & Diff, log & EIA \\
\hline Primary Energy Consumed by the Transportation Sector & Trillion Btu & Diff, perc. $\log$ & EIA \\
\hline Electricity Retail Sales to the Transportation Sector & Trillion Btu & Diff, log & EIA \\
\hline Transportation Sector Electrical System Energy Losses & Trillion Btu & Diff, log & EIA \\
\hline Total Energy Consumed by the Transportation Sector & Trillion Btu & Diff, perc. $\log$ & EIA \\
\hline Crude Oil and Natural Gas Rotary Rigs in Operation, Onshore & Number of rigs & Diff, perc. $\log$ & EIA \\
\hline Crude Oil and Natural Gas Rotary Rigs in Operation, Offshore & Number of rigs & Diff, perc. $\log$ & EIA \\
\hline Crude Oil Rotary Rigs in Operation & Number of rigs & Diff, perc. log & EIA \\
\hline Natural Gas Rotary Rigs in Operation & Number of rigs & Diff, perc. log & EIA \\
\hline Crude Oil and Natural Gas Rotary Rigs in Operation, Total & Number of rigs & Diff, perc. log & EIA \\
\hline Active Well Service Rig Count & Number of rigs & Diff, perc. log & EIA \\
\hline Wells Drilled, Exploratory, Crude Oil & Number of wells & Diff, log & EIA \\
\hline Wells Drilled, Exploratory, Natural Gas & Number of wells & Diff, log & EIA \\
\hline Wells Drilled, Exploratory, Dry & Number of wells & Diff, perc. $\log$ & EIA \\
\hline Wells Drilled, Exploratory, Total & Number of wells & Diff, perc. log & EIA \\
\hline Wells Drilled, Development, Crude Oil & Number of wells & Diff, perc. $\log$ & EIA \\
\hline Wells Drilled, Development, Natural Gas & Number of wells & Diff, perc. log & EIA \\
\hline Wells Drilled, Development, Dry & Number of wells & Diff, perc. log & EIA \\
\hline Wells Drilled, Development, Total & Number of wells & Diff, perc. log & EIA \\
\hline Wells Drilled, Total, Crude Oil & Number of wells & Diff, perc. log & EIA \\
\hline Wells Drilled, Total, Natural Gas & Number of wells & Diff, perc. log & EIA \\
\hline Wells Drilled, Total, Dry & Number of wells & Diff, perc. log & EIA \\
\hline Crude Oil, Natural Gas, and Dry Wells Drilled, Total & Number of wells & Diff, perc. log & EIA \\
\hline Total Footage Drilled & Thousand Feet & Diff, perc. log & EIA \\
\hline Hydroelectric Power Consumed by the Electric Power Sector & Trillion Btu & Diff, perc. log & EIA \\
\hline Geothermal Energy Consumed by the Electric Power Sector & Trillion Btu & Diff, $\log$ & EIA \\
\hline Solar/PV Energy Consumed by the Electric Power Sector & Trillion Btu & Diff, log & EIA \\
\hline Wind Energy Consumed by the Electric Power Sector & Trillion Btu & Diff, log & EIA \\
\hline Wood Energy Consumed by the Electric Power Sector & Trillion Btu & Diff, log & EIA \\
\hline Waste Energy Consumed by the Electric Power Sector & Trillion Btu & Diff, log & EIA \\
\hline Biomass Energy Consumed by the Electric Power Sector & Trillion Btu & Diff, log & EIA \\
\hline Total Renewable Energy Consumed by the Electric Power Sector & Trillion Btu & Diff, perc. $\log$ & EIA \\
\hline Biodiesel Production & Trillion Btu & Diff, log & EIA \\
\hline Fuel Ethanol Feedstock & Trillion Btu & Diff, log & EIA \\
\hline Fuel Ethanol Losses and Co-products & Trillion Btu & Diff, log & EIA \\
\hline Fuel Ethanol Production & Trillion Btu & Diff, perc. $\log$ & EIA \\
\hline Fuel Ethanol Net Imports & Trillion Btu & Diff, log & EIA \\
\hline Fuel Ethanol Stocks & Thousand Barrels & Diff, perc. $\log$ & EIA \\
\hline Fuel Ethanol Consumption & Trillion Btu & Diff, perc. $\log$ & EIA \\
\hline Hydroelectric Power Consumed by the Industrial Sector & Trillion Btu & Diff, $\log$ & EIA \\
\hline Geothermal Energy Consumed by the Industrial Sector & Trillion Btu & Diff, log & EIA \\
\hline Wood Energy Consumed by the Industrial Sector & Trillion Btu & Diff, perc. $\log$ & EIA \\
\hline Waste Energy Consumed by the Industrial Sector & Trillion Btu & Diff, log & EIA \\
\hline Fuel Ethanol Consumed by the Industrial Sector & Trillion Btu & Diff, log & EIA \\
\hline Biomass Losses and Co-products in the Industrial Sector & Trillion Btu & Diff, log & EIA \\
\hline Biomass Energy Consumed by the Industrial Sector & Trillion Btu & Diff, perc. $\log$ & EIA \\
\hline Total Renewable Energy Consumed by the Industrial Sector & Trillion Btu & Diff, perc. log & EIA \\
\hline Fuel Ethanol Consumed by the Transportation Sector & Trillion Btu & Diff, log & EIA \\
\hline Biodiesel Consumed by the Transportation Sector & Trillion Btu & Diff, log & EIA \\
\hline Biomass Energy Consumed by the Transportation Sector & Trillion Btu & Diff, log & EIA \\
\hline Biofuels Production & Trillion Btu & Diff, log & EIA \\
\hline Total Biomass Energy Production & Trillion Btu & Diff, perc. $\log$ & EIA \\
\hline Total Renewable Energy Production & Trillion Btu & Diff, perc. log & EIA \\
\hline Hydroelectric Power Consumption & Trillion Btu & Diff, perc. $\log$ & EIA \\
\hline Geothermal Energy Consumption & Trillion Btu & Diff, $\log$ & EIA \\
\hline Solar/PV Energy Consumption & Trillion Btu & Diff, log & EIA \\
\hline Wind Energy Consumption & Trillion Btu & Diff, log & EIA \\
\hline Wood Energy Consumption & Trillion Btu & Diff, perc. $\log$ & EIA \\
\hline Waste Energy Consumption & Trillion Btu & Diff, $\log$ & EIA \\
\hline Biofuels Consumption & Trillion Btu & Diff, log & EIA \\
\hline Total Biomass Energy Consumption & Trillion Btu & Diff, perc. $\log$ & EIA \\
\hline Total Renewable Energy Consumption & Trillion Btu & Diff, perc. $\log$ & EIA \\
\hline Geothermal Energy Consumed by the Residential Sector & Trillion Btu & Diff, log & EIA \\
\hline Solar/PV Energy Consumed by the Residential Sector & Trillion Btu & Diff, log & EIA \\
\hline Wood Energy Consumed by the Residential Sector & Trillion Btu & Diff, log & EIA \\
\hline Total Renewable Energy Consumed by the Residential Sector & Trillion Btu & Diff, log & EIA \\
\hline Hydroelectric Power Consumed by the Commercial Sector & Trillion Btu & Diff, log & EIA \\
\hline Geothermal Energy Consumed by the Commercial Sector & Trillion Btu & Diff, log & EIA \\
\hline Wood Energy Consumed by the Commercial Sector & Trillion Btu & Diff, log & EIA \\
\hline Waste Energy Consumed by the Commercial Sector & Trillion Btu & Diff, log & EIA \\
\hline Fuel Ethanol Consumed by the Commercial Sector & Trillion Btu & Diff, log & EIA \\
\hline Biomass Energy Consumed by the Commercial Sector & Trillion Btu & Diff, log & EIA \\
\hline Total Renewable Energy Consumed by the Commercial Sector & Trillion Btu & Diff, log & EIA \\
\hline Asphalt and Road Oil Product Supplied & Trillion Btu & Diff, perc. $\log$ & EIA \\
\hline Aviation Gasoline Product Supplied & Trillion Btu & Diff, log & EIA \\
\hline Distillate Fuel Oil Product Supplied & Trillion Btu & Diff, perc. $\log$ & EIA \\
\hline Jet Fuel Product Supplied & Trillion Btu & Diff, perc. $\log$ & EIA \\
\hline Kerosene Product Supplied & Trillion Btu & Diff, perc & EIA \\
\hline Propane/Propylene Product Supplied & Trillion Btu & Diff, perc. $\log$ & EIA \\
\hline
\end{tabular}




\begin{tabular}{|c|c|c|c|}
\hline Series & Unit & Treatment & Source \\
\hline Liquefied Petroleum Gases Product Supplied & Trillion Btu & Diff, perc. $\log$ & EIA \\
\hline Lubricants Product Supplied & Trillion Btu & Diff, log & EIA \\
\hline Motor Gasoline Product Supplied & Trillion Btu & Diff, perc. log & EIA \\
\hline Petroleum Coke Product Supplied & Trillion Btu & Diff, log & EIA \\
\hline Residual Fuel Oil Product Supplied & Trillion Btu & Diff, perc. log & EIA \\
\hline Other Petroleum Products Supplied & Trillion Btu & Diff, perc. log & EIA \\
\hline Total Petroleum Products Supplied & Trillion Btu & Diff, perc. log & EIA \\
\hline Crude Oil Imports, Total & Thousand Barrels per Day & Diff, perc. log & EIA \\
\hline Distillate Fuel Oil Imports & Thousand Barrels per Day & Diff, perc. log & EIA \\
\hline Jet Fuel Imports & Thousand Barrels per Day & Diff, perc. log & EIA \\
\hline Propane/Propylene Imports & Thousand Barrels per Day & Diff, perc. log & EIA \\
\hline Liquefied Petroleum Gases Imports & Thousand Barrels per Day & Diff, perc. $\log$ & EIA \\
\hline Finished Motor Gasoline Imports & Thousand Barrels per Day & Diff, perc. log & EIA \\
\hline Residual Fuel Oil Imports & Thousand Barrels per Day & Diff, perc. log & EIA \\
\hline Other Petroleum Products Imports & Thousand Barrels per Day & Diff, perc. log & EIA \\
\hline Total Petroleum Imports & Thousand Barrels per Day & Diff, perc. log & EIA \\
\hline Crude Oil Exports & Thousand Barrels per Day & Diff, perc. log & EIA \\
\hline Petroleum Products Exports & Thousand Barrels per Day & Diff, perc. log & EIA \\
\hline Total Petroleum Exports & Thousand Barrels per Day & Diff, perc. log & EIA \\
\hline Crude Oil Production, Persian Gulf & Thousand Barrels per Day & Diff, perc. log & EIA \\
\hline Crude Oil Production, Canada & Thousand Barrels per Day & Diff, perc. $\log$ & EIA \\
\hline Crude Oil Production, China & Thousand Barrels per Day & Diff, perc. log & EIA \\
\hline Crude Oil Production, Egypt & Thousand Barrels per Day & Diff, perc. log & EIA \\
\hline Crude Oil Production, Mexico & Thousand Barrels per Day & Diff, perc. log & EIA \\
\hline Crude Oil Production, Norway & Thousand Barrels per Day & Diff, perc. log & EIA \\
\hline Crude Oil Production, Russia & Thousand Barrels per Day & Diff, perc. log & EIA \\
\hline Crude Oil Production, United Kingdom & Thousand Barrels per Day & Diff, perc. log & EIA \\
\hline Crude Oil Production, United States & Thousand Barrels per Day & Diff, perc. log & EIA \\
\hline Crude Oil Production, Total Non-OPEC & Thousand Barrels per Day & Diff, perc. log & EIA \\
\hline Crude Oil Production, World & Thousand Barrels per Day & Diff, perc. log & EIA \\
\hline Crude Oil Production, Algeria & Thousand Barrels per Day & Diff, perc. log & EIA \\
\hline Crude Oil Production, Angola & Thousand Barrels per Day & Diff, perc. log & EIA \\
\hline Crude Oil Production, Ecuador & Thousand Barrels per Day & Diff, perc. log & EIA \\
\hline Crude Oil Production, Indonesia & Thousand Barrels per Day & Diff, perc. log & EIA \\
\hline Crude Oil Production, Iran & Thousand Barrels per Day & Diff, perc. log & EIA \\
\hline Crude Oil Production, Iraq & Thousand Barrels per Day & Diff, perc. log & EIA \\
\hline Crude Oil Production, Kuwait & Thousand Barrels per Day & Diff, perc. log & EIA \\
\hline Crude Oil Production, Libya & Thousand Barrels per Day & Diff, perc. log & EIA \\
\hline Crude Oil Production, Nigeria & Thousand Barrels per Day & Diff, perc. log & EIA \\
\hline Crude Oil Production, Qatar & Thousand Barrels per Day & Diff, perc. $\log$ & EIA \\
\hline Crude Oil Production, Saudi Arabia & Thousand Barrels per Day & Diff, perc. log & EIA \\
\hline Crude Oil Production, United Arab Emirates & Thousand Barrels per Day & Diff, perc. log & EIA \\
\hline Crude Oil Production, Venezuela & Thousand Barrels per Day & Diff, perc. $\log$ & EIA \\
\hline Crude Oil Production, OPEC & Thousand Barrels per Day & Diff, perc. $\log$ & EIA \\
\hline Crude Oil Stocks, SPR & Million Barrels & Diff, perc. log & EIA \\
\hline Crude Oil Stocks, Non-SPR & Million Barrels & Diff, perc. log & EIA \\
\hline Crude Oil Stocks, Total & Million Barrels & Diff, perc. log & EIA \\
\hline Distillate Fuel Oil Stocks & Million Barrels & Diff, perc. log & EIA \\
\hline Jet Fuel Stocks & Million Barrels & Diff, log & EIA \\
\hline Propane/Propylene Stocks & Million Barrels & Diff, log & EIA \\
\hline Liquefied Petroleum Gases Stocks & Million Barrels & Diff, perc. log & EIA \\
\hline Motor Gasoline Stocks & Million Barrels & Diff, perc. log & EIA \\
\hline Residual Fuel Oil Stocks & Million Barrels & Diff, log & EIA \\
\hline Other Petroleum Products Stocks & Million Barrels & Diff, perc. log & EIA \\
\hline Total Petroleum Stocks & Million Barrels & Diff, perc. log & EIA \\
\hline Crude Oil Refinery Net Input & Thousand Barrels per Day & Diff, perc. $\log$ & EIA \\
\hline Natural Gas Plant Liquids Refinery and Blender Net Inputs & Thousand Barrels per Day & Diff, perc. $\log$ & EIA \\
\hline Other Liquids Refinery and Blender Net Inputs & Thousand Barrels per Day & Diff, perc. log & EIA \\
\hline Total Petroleum Refinery and Blender Net Inputs & Thousand Barrels per Day & Diff, perc. log & EIA \\
\hline Distillate Fuel Oil Refinery Net Production & Thousand Barrels per Day & Diff, perc. log & EIA \\
\hline Jet Fuel Refinery Net Production & Thousand Barrels per Day & Diff, perc. log & EIA \\
\hline Propane/Propylene Refinery Net Production & Thousand Barrels per Day & Diff, perc. log & EIA \\
\hline Liquefied Petroleum Gases Refinery Net Production & Thousand Barrels per Day & Diff, perc. log & EIA \\
\hline Finished Motor Gasoline Refinery and Blender Net Production & Thousand Barrels per Day & Diff, perc. log & EIA \\
\hline Residual Fuel Oil Refinery Net Production & Thousand Barrels per Day & Diff, perc. $\log$ & EIA \\
\hline Other Petroleum Products Refinery Net Production & Thousand Barrels per Day & Diff, perc. $\log$ & EIA \\
\hline Total Petroleum Refinery and Blender Net Production & Thousand Barrels per Day & Diff, perc. $\log$ & EIA \\
\hline Petroleum Consumption, France & Thousand Barrels per Day & Diff, perc. log & EIA \\
\hline Petroleum Consumption, Germany & Thousand Barrels per Day & Diff, perc. log & EIA \\
\hline Petroleum Consumption, Italy & Thousand Barrels per Day & Diff, perc. log & EIA \\
\hline Petroleum Consumption, United Kingdom & Thousand Barrels per Day & Diff, perc. log & EIA \\
\hline Petroleum Consumption, OECD Europe & Thousand Barrels per Day & Diff, perc. log & EIA \\
\hline Petroleum Consumption, Canada & Thousand Barrels per Day & Diff, perc. log & EIA \\
\hline Petroleum Consumption, Japan & Thousand Barrels per Day & Diff, perc. log & EIA \\
\hline Petroleum Consumption, South Korea & Thousand Barrels per Day & Diff, perc. log & EIA \\
\hline Petroleum Consumption, United States & Thousand Barrels per Day & Diff, perc. log & EIA \\
\hline Petroleum Consumption, Other OECD & Thousand Barrels per Day & Diff, perc. log & EIA \\
\hline Petroleum Consumption, Total OECD & Thousand Barrels per Day & Diff, perc. log & EIA \\
\hline Petroleum Stocks, France & Million Barrels & Diff, perc. log & EIA \\
\hline Petroleum Stocks, Germany & Million Barrels & Diff, perc. log & EIA \\
\hline Petroleum Stocks, Italy & Million Barrels & Diff, perc. log & EIA \\
\hline Petroleum Stocks, United Kingdom & Million Barrels & Diff, perc. log & EIA \\
\hline Petroleum Stocks, OECD Europe & Million Barrels & Diff, perc. log & EIA \\
\hline Petroleum Stocks, Canada & Million Barrels & Diff, perc. log & EIA \\
\hline Petroleum Stocks, Japan & Million Barrels & Diff, perc. log & EIA \\
\hline Petroleum Stocks, South Korea & Million Barrels & Diff, perc. $\log$ & EIA \\
\hline Petroleum Stocks, United States & Million Barrels & Diff, perc. $\log$ & EIA \\
\hline Petroleum Stocks, Other OECD & Million Barrels & Diff, perc. log & EIA \\
\hline
\end{tabular}




\begin{tabular}{|c|c|c|c|}
\hline Series & Unit & Treatment & Source \\
\hline Petroleum Stocks, Total OECD & Million Barrels & Diff, perc. $\log$ & EIA \\
\hline \multicolumn{4}{|l|}{ MACROECONOMIC AND FINANCIAL DATA } \\
\hline Yield on 10 year Gov US bonds & percent & Diff, log & DS \\
\hline M1 & billion dollars & Diff, log & DS \\
\hline M2 & billion dollars & Diff, log & DS \\
\hline US Bank lending rate & percent & Diff, log & DS \\
\hline Capital utilization rate & percentage index & Diff, log & DS \\
\hline US confidence index rate & index & Diff, log & DS \\
\hline Producer's price index for finished goods & index & Diff, log & DS \\
\hline Producer's price index less food and energy & index & Diff, log & DS \\
\hline Federal Funds rate & percent & Diff, log & DS \\
\hline Consumption expenditure US & billion dollars & Diff, log & DS \\
\hline US CPI index & index & Diff, log & DS \\
\hline US industrial production index & index & Diff, log & DS \\
\hline US house construction index & index & Diff, log & DS \\
\hline Yield on 20years US gov. Bonds & percent & Diff, log & DS \\
\hline Dow Jones index & index & Diff, log & DS \\
\hline Sp500 index & index & Diff, log & DS \\
\hline Yield on US 3yaers gov bonds & percent & Diff, log & DS \\
\hline Crude ligh 1 month open interest & number of contracts & Diff, log & DS \\
\hline Crude light volume front month & number of contracts & Diff, log & DS \\
\hline Crude ligh 3 month open interest & number of contracts & Diff, log & DS \\
\hline Crude light volume 3 month & number of contracts & Diff, log & DS \\
\hline Crude ligh 6 month open interest & number of contracts & Diff, log & DS \\
\hline Crude light volume6 month & number of contracts & Diff, log & DS \\
\hline Crude ligh 12 month open interest & number of contracts & Diff, log & DS \\
\hline Crude light volume 12 month & number of contracts & Diff, log & DS \\
\hline Share price of Total & average price & Diff, log & DS \\
\hline Share price of Exxon & average price & Diff, log & DS \\
\hline Share price of BP & average price & Diff, log & DS \\
\hline Share price of CONOCO & average price & Diff, log & DS \\
\hline Share price of Shell & average price & Diff, log & DS \\
\hline Share price of Chevron & average price & Diff, log & DS \\
\hline JPMorgan global index & index & Diff, log & DS \\
\hline JPMorgan global Eurobond idex & index & Diff, log & DS \\
\hline JPMorgna US gov bond index & price & Diff, log & DS \\
\hline Crude Spread WTI- Brent M+1 NY Cls & price & Diff, log & DS \\
\hline Crude Spread WTI- Brent M+2 NY Cls & price & Diff, log & DS \\
\hline Crude Spread Dubai M-M+1 NY Close & price & Diff, log & DS \\
\hline Crude Spread Dubai $M+1-M+2$ NY Close & price & Diff, log & DS \\
\hline Crude Oil-Dtd Brent UK Close USD/BBL & price & Diff, log & DS \\
\hline Crude Oil-Brent 1Mth Fwd FOB USD/BBL & price & Diff, log & DS \\
\hline US TREASURY BILL RATE - 3 MONTH (EP) & percent & Diff, log & DS \\
\hline USD to EURO noon NY (EP) NADJ & exchange rate & Diff, log & DS \\
\hline Morgan Stanley total index & index & Diff, log & DS \\
\hline US-DS index Oil \& Gas - PRICE INDEX & index & Diff, log & DS \\
\hline Citigroup Bond Index Corporate US & index & Diff, log & DS \\
\hline Citigroup Bond Index Overall & index & Diff, log & DS \\
\hline Citigroup Bond index treasury & index & Diff, log & DS \\
\hline Citigroup bond Index Corporate Bond $1-3$ years, Euro area & index & Diff, log & DS \\
\hline Citigroup Bond Index Total Return index & index & Diff, log & DS \\
\hline Citigroup Bond Index Industrial & index & Diff, log & DS \\
\hline Citigroup Bond Corporate Industrial Worldwide index & index & Diff, log & DS \\
\hline DAX stock market index & index & Diff, log & DS \\
\hline UK stock market index & index & Diff, $\log$ & DS \\
\hline China Industrial production index & index & Diff, log & DS \\
\hline Euro area industrial production index & index & Diff, log & DS \\
\hline USD-GBP exchange rate & exchange rate & Diff, log & DS \\
\hline UK industrial production index & index & Diff, log & DS \\
\hline World Dow-Jones industrial performance & index & Diff, log & DS \\
\hline CBOE VIX (implied volatility index) & index & Diff, log & DS \\
\hline BS $1 \mathrm{M}$ & index & Diff, log & $\mathrm{ECB}$ \\
\hline BS $3 \mathrm{M}$ & index & Diff, log & $\mathrm{ECB}$ \\
\hline BS $6 \mathrm{M}$ & index & Diff, log & $\mathrm{ECB}$ \\
\hline BS 1Y & index & Diff, log & $\mathrm{ECB}$ \\
\hline NYMEX Natural gas 1 month & price & Diff, log & DS \\
\hline NYMEX Natural gas 3 month & price & Diff, log & DS \\
\hline NYMEX Natural gas 6 month & price & Diff, log & DS \\
\hline NYMEX Heating oil 1 month & price & Diff, log & DS \\
\hline NYMEX Heating oil 3 month & price & Diff, log & DS \\
\hline
\end{tabular}

Legend:

EIA: Energy Information Administration.

DS: Datastream

ECB: European Central Bank

Diff: first difference of level.

Diff, log: first difference of $\log$.

Diff, perc: first difference of percentage value.

Diff, perc. log: first difference of log of percentage value. 
Table 1: Variance explained by the factors

\begin{tabular}{lcc} 
Factor & $R^{2}$ & First autocorr. coeff. \\
\hline 1 & 0.1823 & 0.3241 \\
2 & 0.3065 & -0.4735 \\
3 & 0.3961 & 0.4727 \\
4 & 0.4758 & 0.1521 \\
\hline
\end{tabular}


Table 2: Share of explained variance of highly-correlated series

\begin{tabular}{lc} 
Factor 1 (18\% to total variance) & $R^{2}$ \\
\hline Landed Cost of Crude Oil Imports From All Non-OPEC Countries & 0.85 \\
Average F.O.B. Cost of Crude Oil Imports From All Non-OPEC Countries & 0.83 \\
Refiner Price of No. 2 Diesel Fuel for Resale & 0.80 \\
Landed Cost of Crude Oil Imports From Mexico & 0.80 \\
Refiner Price of No. 2 Diesel Fuel to End Users & 0.79
\end{tabular}

Factor 2 (12\% to total variance)

Motor Gasoline Stocks (Including Blending Components and Gasohol) $\quad 0.84$

Volume of Crude Oil Futures 3-Month Contracts 0.46

Other Petroleum Products Stocks 0.38

Finished Motor Gasoline Imports $\quad 0.31$

Petroleum Stocks, Other OECD $\quad 0.27$

Factor 3 (9\% to total variance)

Propane/Propylene Product Supplied 0.31

Refiner Price of Kerosene to End Users $\quad 0.18$

Liquefied Petroleum Gases Product Supplied $\quad 0.17$

Refiner Price of Propane (Consumer Grade) for Resale $\quad 0.12$

Refiner Price of Kerosene for Resale 0.11

Factor 4 ( $8 \%$ to total variance)

Open Interest on 12-Month Crude Oil Futures 0.19

Open Interest on 6-Month Crude Oil Futures 0.18

$\begin{array}{ll}\text { Jet Fuel Refinery Net Production } & 0.17\end{array}$

Total Petroleum Refinery and Blender Net Inputs $\quad 0.17$

Volume 6-Month Crude Oil Futures 0.15

Legend: This table reports $R^{2}$ of univariate regressions of factors on macro variables. I report the five variables with the highest correlation with the factors. 
Table 3: Correlations between factors and returns

\begin{tabular}{lcccc}
\hline & Factor 1 & Factor 2 & Factor 3 & Factor 4 \\
& \multicolumn{4}{r}{ (a) Contemporaneous correlation } \\
\cline { 2 - 5 } & \multicolumn{4}{r}{} \\
\cline { 2 - 5 } 1-month & 0.896 & -0.129 & -0.019 & 0.109 \\
3-month & 0.887 & -0.143 & -0.023 & 0.119 \\
6-month & 0.859 & -0.085 & -0.126 & 0.111 \\
12-month & 0.299 & -0.079 & -0.051 & 0.122 \\
& & & & \\
\hline
\end{tabular}

(b) Correlation with 1-month lagged factors

\begin{tabular}{lcccc} 
& & & & \\
\cline { 2 - 5 } 1-month & 0.146 & 0.067 & 0.015 & 0.187 \\
3-month & 0.153 & 0.071 & 0.018 & 0.182 \\
6-month & 0.202 & 0.017 & -0.056 & 0.096 \\
12-month & 0.144 & -0.093 & -0.131 & 0.0006 \\
\hline
\end{tabular}

(c) Correlation with 6-month lagged factors

\begin{tabular}{lcccc}
\cline { 2 - 5 } 1-month & -0.005 & -0.009 & 0.154 & 0.015 \\
3-month & 0.005 & -0.001 & 0.154 & 0.014 \\
6-month & 0.049 & 0.041 & 0.143 & 0.049 \\
12-month & -0.035 & 0.084 & 0.033 & 0.180 \\
& & & & \\
\hline
\end{tabular}


Table 4: Unrestricted regressions of yields on factors

\begin{tabular}{lcccc}
\hline & 1-month & 3 -month & 6 -month & 12-month \\
\cline { 2 - 5 } & & & & \\
Factor 1 & 0.887 & 0.900 & 0.859 & 0.298 \\
& {$[0.030]$} & $\begin{array}{c}0.029] \\
{[0.036]}\end{array}$ & {$[0.067]$} \\
Factor 2 & -0.143 & -0.133 & -0.084 & -0.079 \\
& {$[0.035]$} & {$[0.028]$} & {$[0.035]$} & {$[0.068]$} \\
Factor 3 & -0.023 & -0.068 & -0.126 & -0.050 \\
& {$[0.029]$} & {$[0.031]$} & {$[0.033]$} & {$[0.069]$} \\
Factor 4 & 0.119 & 0.098 & 0.110 & 0.122 \\
& {$[0.031]$} & {$[0.029]$} & {$[0.035]$} & {$[0.069]$} \\
\hline \multirow{2}{*}{$R^{2}$} & 0.823 & 0.843 & 0.774 & 0.113 \\
\hline
\end{tabular}

Legend: Brackets report standard errors. Constants are omitted. 
Table 5: Unit-root tests

\begin{tabular}{|c|c|c|c|c|c|c|c|c|}
\hline & \multicolumn{4}{|c|}{ Yields } & \multicolumn{4}{|c|}{ Factors } \\
\hline & 1-month & 3-month & 6-month & 12-month & 1 & 2 & 3 & 4 \\
\hline Phillips-Perron $\mathrm{Mz}_{\alpha}$ & -94.742 & -94.908 & -93.516 & -42.113 & -122.625 & -16.542 & -20.005 & -15.260 \\
\hline Phillips-Perron $\mathrm{Mz}_{t}$ & -6.881 & -6.888 & -6.836 & -4.586 & -7.830 & -2.679 & -2.888 & -2.871 \\
\hline Sargan-Bhargava & 0.072 & 0.097 & 0.072 & 0.108 & 0.064 & 0.056 & 0.144 & 0.126 \\
\hline Mod. point-optimal & 0.260 & 0.258 & 0.266 & 0.588 & 0.199 & 0.329 & 1.033 & 0.837 \\
\hline
\end{tabular}

Legend: The auxiliary models include a constant. The lag lengths are chosen using the modified BIC dicussed in Perron and Ng (2001). The modified Phillips-Perron are all outlined in Perron and $\mathrm{Ng}$ (1996), the point-optimal test is from Elliott, Rothenberg, and Stock (1996) and is amended in Perron and Ng (2001) together with Sargan and Bhargava (1983)'s test. All the test statistics are significant at the $5 \%$ level. 
Table 6: Parameter estimates of the FAVAR model

\begin{tabular}{|c|c|c|c|c|c|c|c|c|}
\hline \multirow[b]{2}{*}{ Factor 1} & \multicolumn{8}{|c|}{$\Gamma_{1}$} \\
\hline & $\begin{array}{l}0.657 \\
{[0.193]}\end{array}$ & $\begin{array}{c}-0.120 \\
{[0.086]}\end{array}$ & $\begin{array}{l}0.073 \\
{[0.079]}\end{array}$ & $\begin{array}{l}0.208 \\
{[0.071]}\end{array}$ & $\begin{array}{l}0.279 \\
{[0.629]}\end{array}$ & $\begin{array}{c}-0.496 \\
{[0.635]}\end{array}$ & $\begin{array}{c}-0.101 \\
{[0.192]}\end{array}$ & $\begin{array}{l}0.086 \\
{[0.083]}\end{array}$ \\
\hline Factor 2 & $\underset{[0.158]}{-.0004}$ & $\begin{array}{c}-0.583 \\
{[0.071]}\end{array}$ & $\begin{array}{c}-0.036 \\
{[0.065]}\end{array}$ & $\begin{array}{c}-0.224 \\
{[0.058]}\end{array}$ & $\begin{array}{c}-0.194 \\
{[0.517]}\end{array}$ & $\begin{array}{l}0.459 \\
{[0.521]}\end{array}$ & $\begin{array}{c}-0.446 \\
{[0.156]}\end{array}$ & $\begin{array}{l}0.123 \\
{[0.068]}\end{array}$ \\
\hline Factor 3 & $\begin{array}{c}-0.387 \\
{[0.174]}\end{array}$ & $\begin{array}{c}-0.096 \\
{[0.078]}\end{array}$ & $\begin{array}{l}0.571 \\
{[0.072]}\end{array}$ & $\begin{array}{l}0.161 \\
{[0.064]}\end{array}$ & $\begin{array}{l}0.874 \\
{[0.569]}\end{array}$ & $\begin{array}{c}-0.680 \\
{[0.575]}\end{array}$ & $\begin{array}{c}-0.0008 \\
{[0.175]}\end{array}$ & $\begin{array}{l}0.009 \\
{[0.075]}\end{array}$ \\
\hline Factor 4 & $\begin{array}{c}-0.243 \\
{[0.195]}\end{array}$ & $\begin{array}{c}-0.018 \\
{[0.087]}\end{array}$ & $\begin{array}{c}-0.031 \\
{[0.081]}\end{array}$ & $\begin{array}{l}0.126 \\
{[0.072]}\end{array}$ & $\begin{array}{l}0.302 \\
{[0.636]}\end{array}$ & $\begin{array}{c}-0.203 \\
{[0.642]}\end{array}$ & $\begin{array}{c}-0.016 \\
{[0.195]}\end{array}$ & $\begin{array}{c}-0.010 \\
{[0.083]}\end{array}$ \\
\hline 1-month & $\begin{array}{l}0.588 \\
{[0.207]}\end{array}$ & $\begin{array}{c}-0.016 \\
{[0.092]}\end{array}$ & $\begin{array}{l}0.065 \\
{[0.086]}\end{array}$ & $\begin{array}{l}0.225 \\
{[0.076]}\end{array}$ & $\begin{array}{l}0.632 \\
{[0.675]}\end{array}$ & $\begin{array}{c}-0.962 \\
{[0.681]}\end{array}$ & $\begin{array}{c}-0.141 \\
{[0.206]}\end{array}$ & $\begin{array}{l}0.085 \\
{[0.089]}\end{array}$ \\
\hline 3-month & $\begin{array}{l}0.566 \\
{[0.204]}\end{array}$ & $\begin{array}{c}-0.002 \\
{[0.091]}\end{array}$ & $\begin{array}{l}0.062 \\
{[0.084]}\end{array}$ & $\begin{array}{l}0.220 \\
{[0.075]}\end{array}$ & $\begin{array}{l}1.315 \\
{[0.666]}\end{array}$ & $\begin{array}{c}-1.639 \\
{[0.672]}\end{array}$ & $\begin{array}{c}-0.118 \\
{[0.204]}\end{array}$ & $\begin{array}{l}0.084 \\
{[0.087]}\end{array}$ \\
\hline 6-month & $\begin{array}{l}0.534 \\
{[0.211]}\end{array}$ & $\begin{array}{c}-0.032 \\
{[0.094]}\end{array}$ & $\begin{array}{c}-0.042 \\
{[0.087]}\end{array}$ & $\begin{array}{l}0.126 \\
{[0.078]}\end{array}$ & $\begin{array}{l}0.798 \\
{[0.687]}\end{array}$ & $\begin{array}{c}-0.889 \\
{[0.693]}\end{array}$ & $\begin{array}{c}-0.194 \\
{[0.211]}\end{array}$ & $\begin{array}{c}-0.083 \\
{[0.091]}\end{array}$ \\
\hline \multirow[t]{2}{*}{ 12-month } & $\begin{array}{l}0.311 \\
{[0.186]} \\
\end{array}$ & $\begin{array}{c}-0.061 \\
{[0.083]} \\
\end{array}$ & $\begin{array}{c}-0.088 \\
{[0.077]}\end{array}$ & $\begin{array}{l}0.043 \\
{[0.068]} \\
\end{array}$ & $\begin{array}{c}-0.476 \\
{[0.607]} \\
\end{array}$ & $\begin{array}{l}0.169 \\
{[0.612]} \\
\end{array}$ & $\begin{array}{l}0.382 \\
{[0.186]} \\
\end{array}$ & $\begin{array}{c}-0.523 \\
{[0.081]} \\
\end{array}$ \\
\hline & \multicolumn{8}{|c|}{$\Gamma_{2}$} \\
\hline Factor 1 & $\begin{array}{l}-0.319 \\
{[-0.014]}\end{array}$ & $\begin{array}{l}0.031 \\
{[0.079]}\end{array}$ & $\begin{array}{c}-0.223 \\
{[0.080]}\end{array}$ & $\begin{array}{l}0.049 \\
{[0.072]}\end{array}$ & $\begin{array}{l}0.976 \\
{[0.636]}\end{array}$ & $\begin{array}{c}-0.953 \\
0.631]\end{array}$ & $\begin{array}{l}0.097 \\
{[0.196]}\end{array}$ & $\begin{array}{c}-0.081 \\
{[0.085]}\end{array}$ \\
\hline Factor 2 & $\begin{array}{c}-0.015 \\
{[0.138]}\end{array}$ & $\begin{array}{c}-0.145 \\
{[0.064]}\end{array}$ & $\begin{array}{l}0.156 \\
{[0.066]}\end{array}$ & $\begin{array}{l}0.322 \\
{[0.052]}\end{array}$ & $\begin{array}{l}0.168 \\
{[0.523]}\end{array}$ & $\begin{array}{c}-0.031 \\
{[0.518]}\end{array}$ & $\begin{array}{c}-0.414 \\
{[0.161]}\end{array}$ & $\begin{array}{l}0.027 \\
{[0.070]}\end{array}$ \\
\hline Factor 3 & $\begin{array}{c}-0.167 \\
{[0.152]}\end{array}$ & $\begin{array}{c}-0.327 \\
{[0.071]}\end{array}$ & $\begin{array}{c}-0.144 \\
{[0.072]}\end{array}$ & $\begin{array}{c}-0.081 \\
{[0.065]}\end{array}$ & $\begin{array}{l}0.511 \\
{[0.576]}\end{array}$ & $\begin{array}{c}-0.160 \\
{[0.571]}\end{array}$ & $\begin{array}{c}-0.056 \\
{[0.178]}\end{array}$ & $\begin{array}{c}-0.034 \\
{[0.078]}\end{array}$ \\
\hline Factor 4 & $\begin{array}{l}0.228 \\
{[0.170]}\end{array}$ & $\begin{array}{c}-0.221 \\
{[0.079]}\end{array}$ & $\begin{array}{l}0.405 \\
{[0.081]}\end{array}$ & $\begin{array}{c}-0.009 \\
{[0.073]}\end{array}$ & $\begin{array}{c}-0.966 \\
{[0.643]}\end{array}$ & $\begin{array}{l}0.689 \\
{[0.637]}\end{array}$ & $\begin{array}{l}0.064 \\
{[0.199]}\end{array}$ & $\begin{array}{c}-0.061 \\
{[0.087]}\end{array}$ \\
\hline 1-month & $\begin{array}{c}-0.131 \\
{[0.181]}\end{array}$ & $\begin{array}{l}0.064 \\
{[0.084]}\end{array}$ & $\begin{array}{c}-0.234 \\
{[0.085]}\end{array}$ & $\begin{array}{l}0.048 \\
{[0.077]}\end{array}$ & $\begin{array}{l}1.179 \\
{[0.682]}\end{array}$ & $\begin{array}{c}-1.261 \\
{[0.676]}\end{array}$ & $\begin{array}{l}0.072 \\
{[0.211]}\end{array}$ & $\begin{array}{c}-0.067 \\
{[0.091]}\end{array}$ \\
\hline 3-month & $\begin{array}{c}-0.141 \\
{[0.178]}\end{array}$ & $\begin{array}{l}0.076 \\
{[0.083]}\end{array}$ & $\begin{array}{c}-0.222 \\
{[0.087]}\end{array}$ & $\begin{array}{l}0.044 \\
{[0.076]}\end{array}$ & $\begin{array}{l}1.493 \\
{[0.673]}\end{array}$ & $\begin{array}{c}-1.607 \\
{[0.667]}\end{array}$ & $\begin{array}{l}0.119 \\
{[0.208]}\end{array}$ & $\begin{array}{c}-0.070 \\
{[0.091]}\end{array}$ \\
\hline 6-month & $\begin{array}{c}-0.328 \\
{[0.184]}\end{array}$ & $\begin{array}{l}0.054 \\
{[0.086]}\end{array}$ & $\begin{array}{c}-0.158 \\
{[0.087]}\end{array}$ & $\begin{array}{l}0.017 \\
{[0.079]}\end{array}$ & $\begin{array}{l}1.212 \\
{[0.695]}\end{array}$ & $\begin{array}{c}-1.118 \\
{[0.689]}\end{array}$ & $\begin{array}{l}0.170 \\
{[0.215]}\end{array}$ & $\begin{array}{c}-0.182 \\
{[0.094]}\end{array}$ \\
\hline \multirow[t]{2}{*}{ 12-month } & $\begin{array}{l}0.038 \\
{[0.162]}\end{array}$ & $\begin{array}{c}-0.102 \\
{[0.076]}\end{array}$ & $\begin{array}{c}-0.059 \\
{[0.077]}\end{array}$ & $\begin{array}{l}0.052 \\
{[0.069]}\end{array}$ & $\begin{array}{c}-0.079 \\
{[0.614]} \\
\end{array}$ & $\begin{array}{l}0.081 \\
{[0.609]}\end{array}$ & $\begin{array}{l}0.021 \\
{[0.190]}\end{array}$ & $\begin{array}{c}-0.460 \\
{[0.083]}\end{array}$ \\
\hline & \multicolumn{8}{|c|}{$\Sigma$} \\
\hline Factor 1 & 0.797 & & & & & & & \\
\hline Factor 2 & -0.029 & 0.538 & & & & & & \\
\hline Factor 3 & 0.002 & -0.072 & 0.653 & & & & & \\
\hline Factor 4 & 0.138 & -0.026 & -0.116 & 0.815 & & & & \\
\hline 1-month & 0.774 & -0.117 & -0.029 & 0.225 & 0.916 & & & \\
\hline 3-month & 0.759 & -0.122 & -0.036 & 0.234 & 0.899 & 0.893 & & \\
\hline 6-month & 0.764 & -0.074 & -0.105 & 0.226 & 0.855 & 0.850 & 0.951 & \\
\hline 12-month & 0.288 & -0.045 & 0.014 & 0.144 & 0.322 & 0.319 & 0.390 & 0.742 \\
\hline
\end{tabular}

Legend: Brackets report standard errors. Constants are omitted. 
Table 7: Pairwise Granger-causality $F$ tests

\begin{tabular}{|c|c|c|c|c|}
\hline & Factor 1 & Factor 2 & Factor 3 & Factor 4 \\
\hline & \multicolumn{4}{|c|}{ does not Granger-cause } \\
\hline 1-month & $\begin{array}{l}2.685 \\
(0.071)\end{array}$ & $\begin{array}{l}0.405 \\
(0.667)\end{array}$ & $\begin{array}{l}3.913 \\
(0.022)\end{array}$ & $\begin{array}{l}3.405 \\
(0.035)\end{array}$ \\
\hline 3-month & $\begin{array}{l}3.661 \\
(0.028)\end{array}$ & $\begin{array}{l}0.450 \\
(0.638)\end{array}$ & $\begin{array}{l}3.794 \\
(0.024)\end{array}$ & $\begin{array}{l}3.139 \\
(0.046)\end{array}$ \\
\hline 6-month & $\begin{array}{l}3.717 \\
(0.026)\end{array}$ & $\begin{array}{l}0.039 \\
(0.962)\end{array}$ & $\begin{array}{l}1.879 \\
(0.155)\end{array}$ & $\begin{array}{l}1.245 \\
(0.204)\end{array}$ \\
\hline \multirow[t]{3}{*}{ 12-month } & $\begin{array}{c}15.351 \\
(7 e-7)\end{array}$ & $\begin{array}{l}1.789 \\
(0.169)\end{array}$ & $\begin{array}{l}2.727 \\
(0.068)\end{array}$ & $\begin{array}{l}0.831 \\
(0.437)\end{array}$ \\
\hline & 1-month & 3-month & 6-month & 12-month \\
\hline & \multicolumn{4}{|c|}{ does not Granger-cause } \\
\hline Factor 1 & $\begin{array}{l}0.281 \\
(0.756)\end{array}$ & $\begin{array}{l}0.100 \\
(0.905)\end{array}$ & $\begin{array}{l}1.065 \\
(0.347)\end{array}$ & $\begin{array}{l}2.381 \\
(0.095)\end{array}$ \\
\hline Factor 2 & $\begin{array}{l}6.512 \\
(0.002)\end{array}$ & $\begin{array}{l}6.550 \\
(0.002)\end{array}$ & $\begin{array}{c}12.584 \\
(7 e-6)\end{array}$ & $\begin{array}{l}2.521 \\
(0.083)\end{array}$ \\
\hline Factor 3 & $\begin{array}{l}2.214 \\
(0.112)\end{array}$ & $\begin{array}{l}2.475 \\
(0.009)\end{array}$ & $\begin{array}{l}1.729 \\
(0.180)\end{array}$ & $\begin{array}{l}0.524 \\
(0.592)\end{array}$ \\
\hline Factor 4 & $\begin{array}{l}1.833 \\
(0.162)\end{array}$ & $\begin{array}{l}1.901 \\
(0.152)\end{array}$ & $\begin{array}{l}2.937 \\
(0.055)\end{array}$ & $\begin{array}{l}2.040 \\
(0.132)\end{array}$ \\
\hline
\end{tabular}

Legend: This table reports pairwise $F$ statistics and their $p$-values (in brackets). 


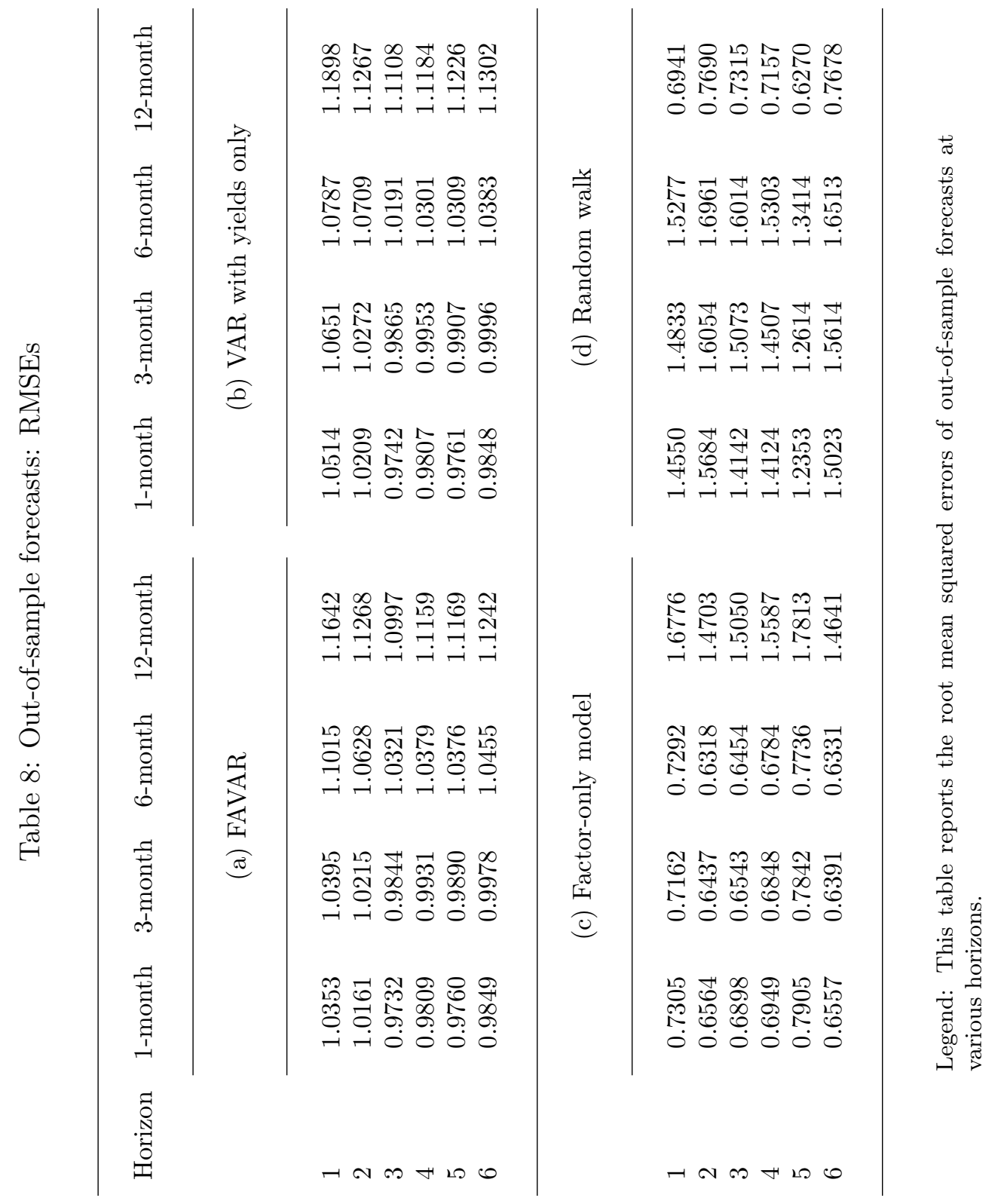




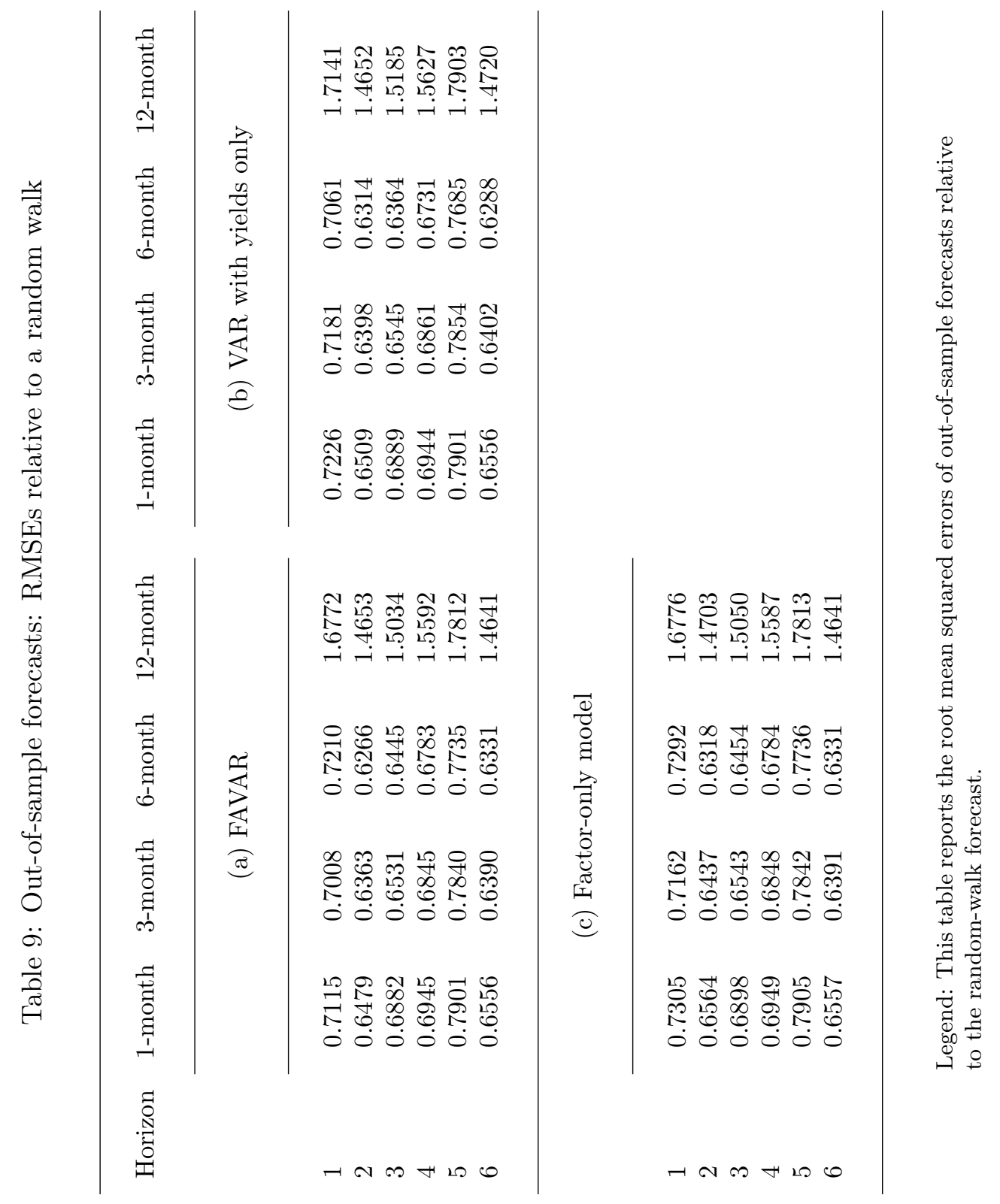



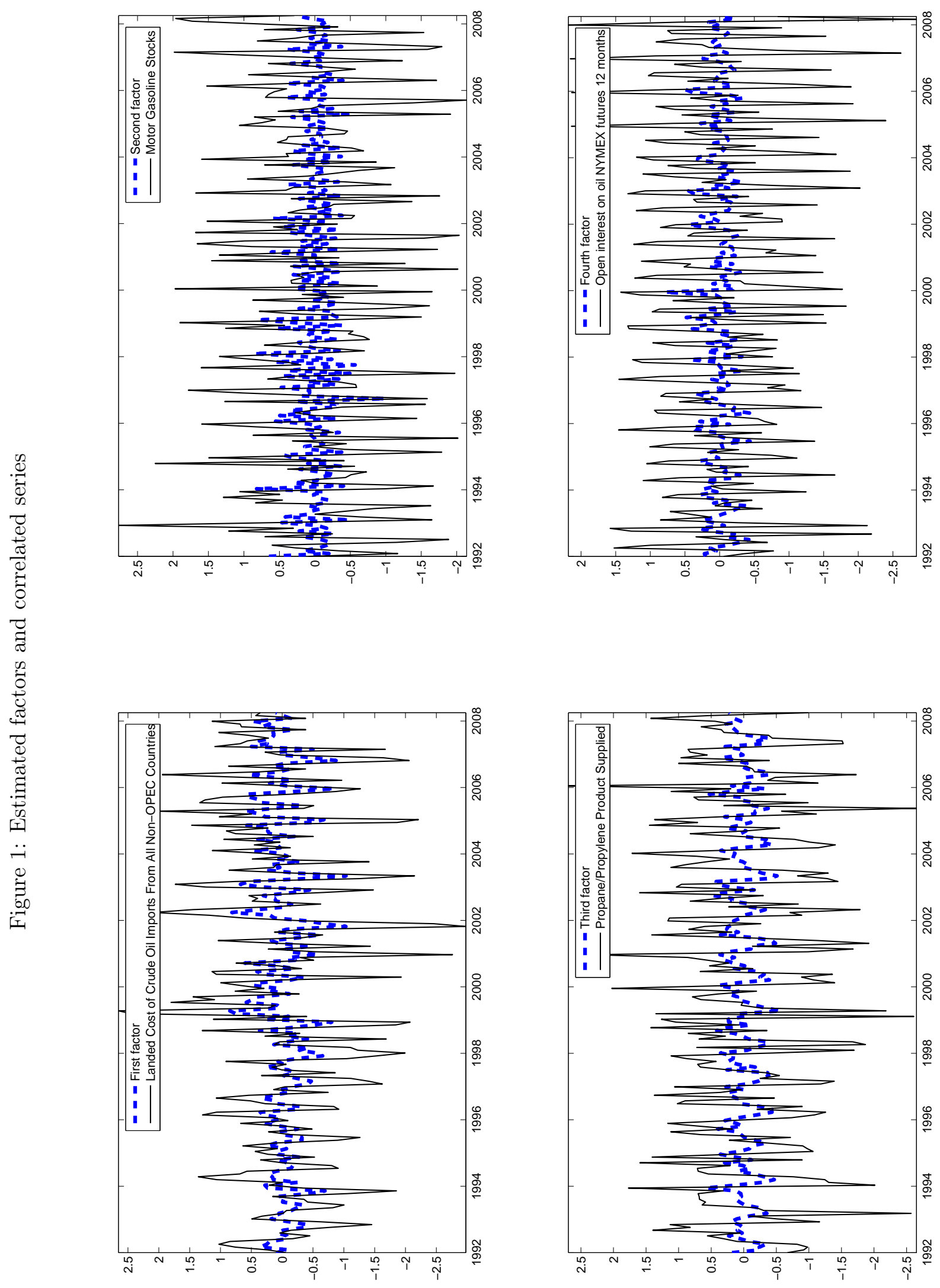

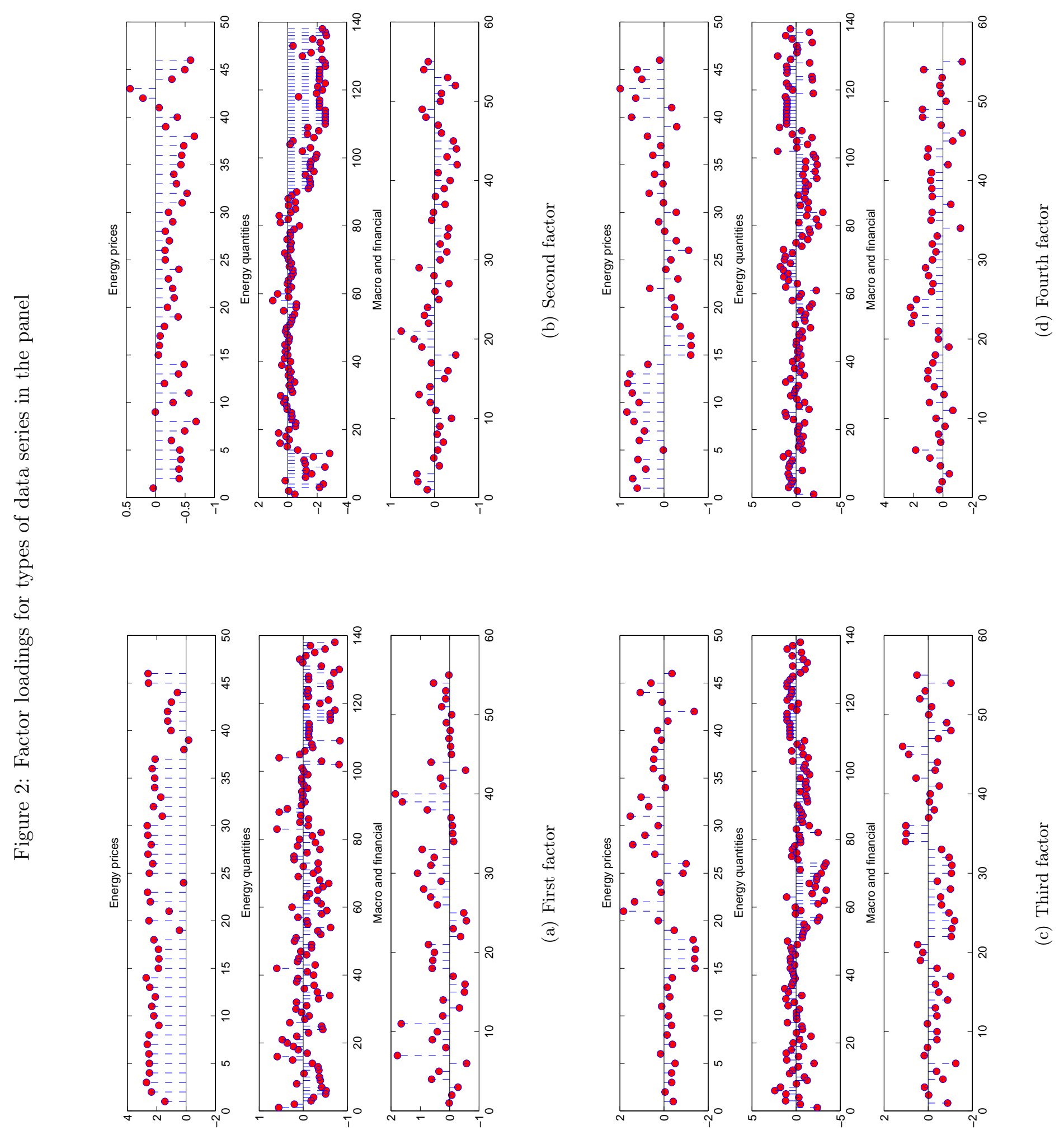

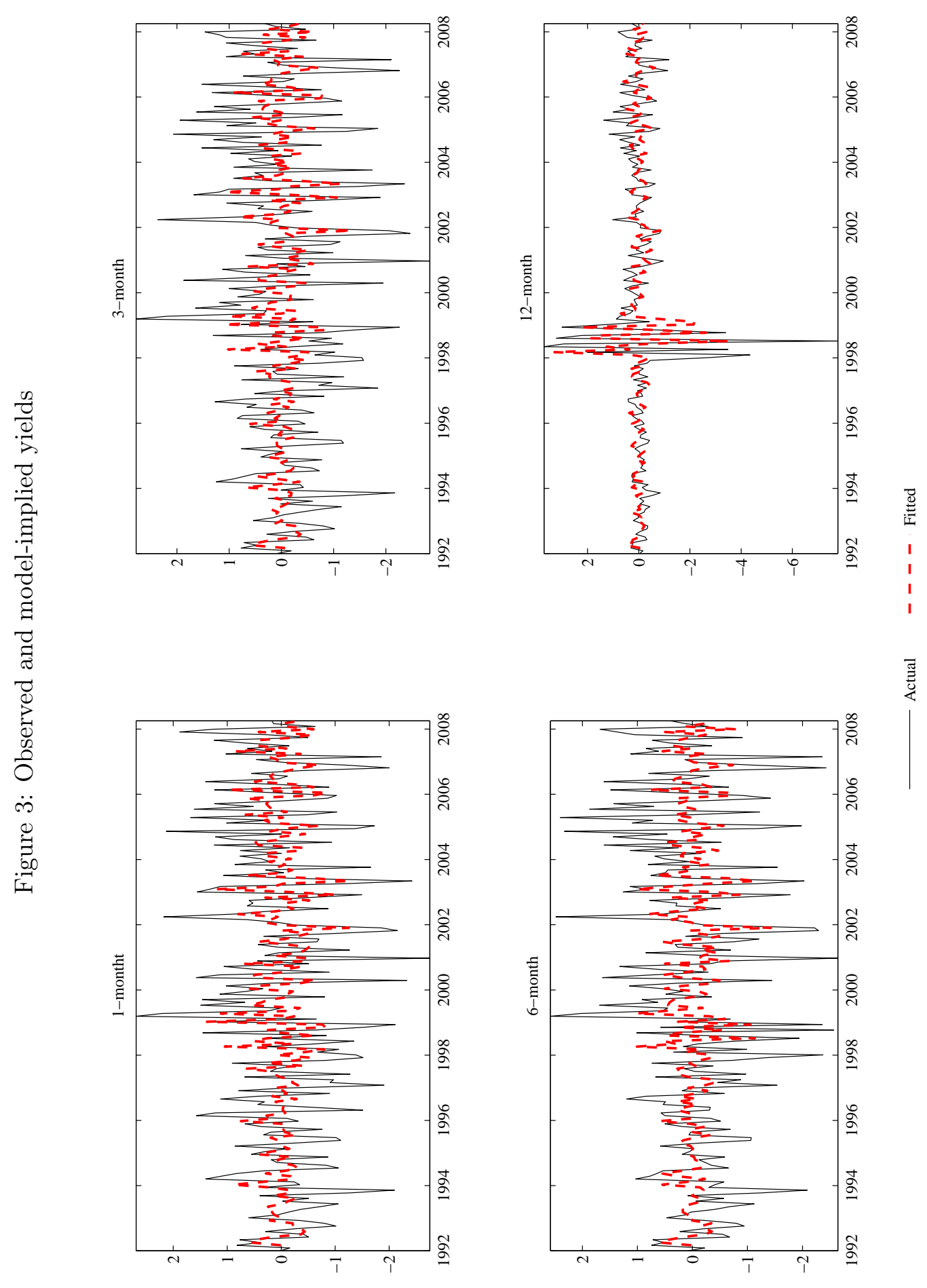